\title{
Gold-catalyzed direct alkynylation of tryptophan in peptides using TIPS-EBX
}

\author{
Gergely L. Tolnai ${ }^{1,2}$, Jonathan P. Brand ${ }^{1,3}$ and Jerome Waser ${ }^{* 1}$
}

\section{Letter}

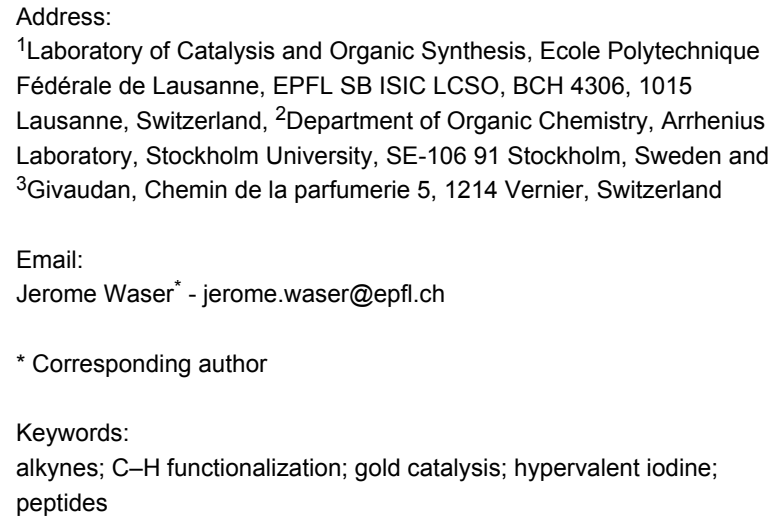

\author{
Beilstein J. Org. Chem. 2016, 12, 745-749. \\ doi:10.3762/bjoc. 12.74 \\ Received: 07 February 2016 \\ Accepted: 06 April 2016 \\ Published: 19 April 2016 \\ This article is part of the Thematic Series "C-H \\ Functionalization/activation in organic synthesis". \\ Guest Editor: R. Sarpong \\ (C) 2016 Tolnai et al; licensee Beilstein-Institut. \\ License and terms: see end of document.
}

\begin{abstract}
The selective functionalization of peptides containing only natural amino acids is important for the modification of biomolecules. In particular, the installation of an alkyne as a useful handle for bioconjugation is highly attractive, but the use of a carbon linker is usually required. Herein, we report the gold-catalyzed direct alkynylation of tryptophan in peptides using the hypervalent iodine reagent TIPS-EBX (1-[(triisopropylsilyl)ethynyl]-1,2-benziodoxol-3(1H)-one). The reaction proceeded in 50-78\% yield under mild conditions and could be applied to peptides containing other nucleophilic and aromatic amino acids, such as serine, phenylalanine or tyrosine.
\end{abstract}

\section{Introduction}

Alkynes have always been important building blocks in synthetic organic chemistry. Recently, they have attracted also strong interest for applications in materials science and chemical biology [1]. One of the most important transformations of alkynes is the copper-catalyzed [3 3 ] cycloaddition with azides, which can be performed under mild conditions in the presence of multiple functional groups, and has therefore found broad applications for the modification of biomolecules and polymers [2-5]. But before the unique reactivity of the triple bond can be unravelled, it is necessary to introduce it onto the desired molecules. In this context, the modification of natural peptides and proteins is highly attractive, and it has been the target of intensive research in the last decades (Figure 1) [6-11]. The functionalization of highly reactive cysteine, lysine and the $\mathrm{N}$-terminus has been particularly successful [12-17], whereas the more challenging modification of the electron-rich aromatic residues of tyrosine [18-20] and tryptophan [21-31] has been the focus of recent interest. As tryptophan is a rare amino acid, its functionalization is especially interesting. It has been achieved in the past for example by Francis and co-workers and 
Ball and co-workers using rhodium-catalyzed carbene-insertion reactions [21-23] or via direct $\mathrm{C}-\mathrm{H}$ arylation [24-29]. If the installation of alkynes on peptides or proteins is desired, an indirect method using a linker is used, for example an alkylation reaction of cysteine. The direct introduction of an alkyne onto the biomolecule would be interesting to profit from modified electronic and spectroscopic properties. However, the direct alkynylation of peptides or proteins is usually based on the use of the Sonogashira reaction, which requires modified non-natural amino acids [32,33].

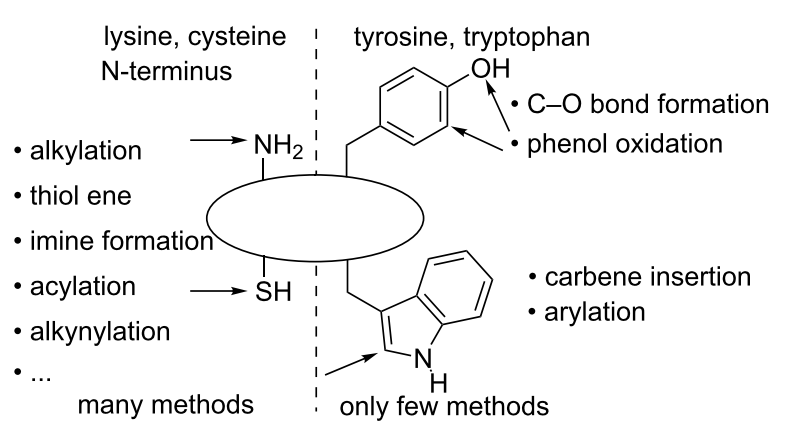

Figure 1: Functionalization of natural peptides and proteins: state of the art.

In 2013, our group reported the alkynylation of thiols using the hypervalent iodine reagent TIPS-EBX (1a, 1-[(triisopropylsilyl)ethynyl]-1,2-benziodoxol-3(1H)-one) (Scheme 1A) [34]. The reaction was almost instantaneous. It was highly chemoselective for thiols in the presence of other nucleophilic functional groups. The alkynylation could be therefore applied to cysteine-containing peptides. The scope of the reaction could be later extended to a broad range of aliphatic and aromatic alkynes [35]. In 2015, the efficiency of the reaction for the functionalization of proteins both in cell lysates and in the living cell was finally demonstrated [36].

Even if the alkynylation of cysteines is an important method, thiols are often part of disulfide bonds in folded proteins, and therefore difficult to access. Reduction and unfolding, or protein engineering to install more accessible cysteines, are usually required. For these reasons, it is important to develop selective alkynylation methods in order to functionalize other amino acids. The direct $\mathrm{C}-\mathrm{H}$ functionalization of aromatic compounds is an attractive method for the modification of biomolecules without the need for non-natural amino acids. However, the multiple functional groups present in biomolecules make such a process highly challenging. Based on our previous work on the alkynylation of indoles using TIPS-EBX (1a) and a gold catalysis $[37,38]$, we wondered if this transformation could be extend-
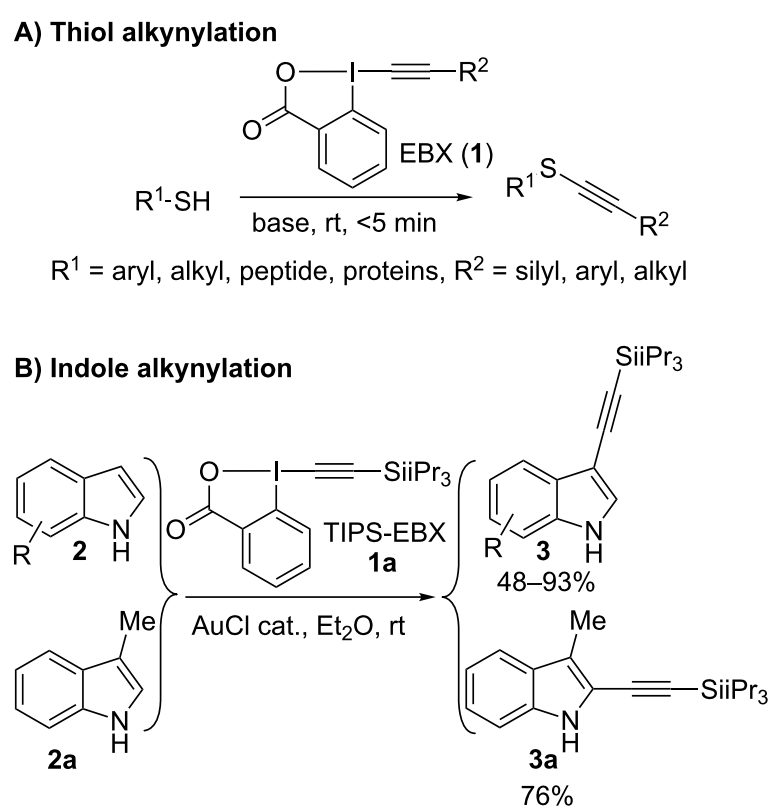

C) This and Hansen's work: tryptophan alkynylation
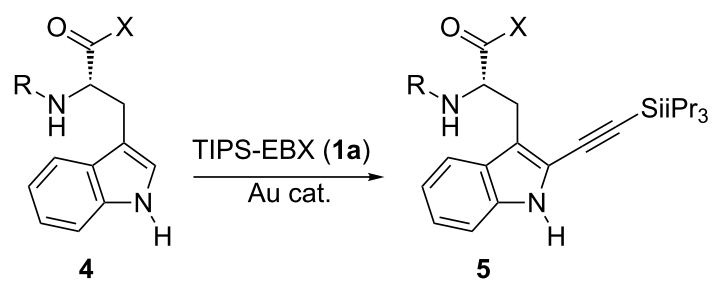

Scheme 1: Alkynylation with EBX reagents.

ed to tryptophan-containing peptides. Even if the reaction gave C3-alkynylation for C3-unsubstituted indoles, we demonstrated that C2-alkynylation could be achieved on skatole (2a, Scheme 1B) [37]. Very recently, Hansen et al. indeed reported a modified protocol using a gold catalyst and TIPS-EBX (1a) for the alkynylation of tryptophan-containing peptides and even proteins (Scheme 1C) [39]. This recent disclosure motivated us to report our own work on this transformation, resulting in an efficient direct alkynylation of tryptophan-containing peptides.

\section{Results and Discussion}

We started our investigation by attempting the alkynylation of valine-tryptophan dipeptide $\mathbf{4 a}$ as model substrate (Table 1). An often used carboxybenzyl (Cbz, Z) protecting group was chosen. Examining this substrate will tell if $\mathrm{C} 2$-alkynylation is possible in the presence of an ester, a carbamate and an amide protecting group. A promising result was obtained with $5 \mathrm{~mol} \%$ gold chloride as catalyst at room temperature in acetonitrile (Table 1, entry 1). Although the reaction did not go to completion even after two days, the desired $\mathrm{C} 2$ alkynylation 
product $5 \mathbf{a}$ was obtained in $44 \%$ yield. The yield could be increased to $72 \%$ when the reaction was performed at $40{ }^{\circ} \mathrm{C}$ (Table 1, entry 2). No further improvement was observed at higher temperature (Table 1 , entry 3 ). The product $\mathbf{5 a}$ could also be obtained in a broad range of other solvents, as long as the solubility of the substrate $\mathbf{4 a}$ and TIPS-EBX (1a) was sufficient (Table 1, entries 4-8). The best yield was obtained in acetonitrile (Table 1, entry 2). Although the presence of water slowed down the reaction, the desired product could still be obtained in $41 \%$ yield (Table 1, entry 9). Monitoring the reaction over time showed that $34 \%$ of product $5 \mathbf{a}$ was already formed after 20 min (Table 1, entry 10), but the reaction then slowed down significantly, with $67 \%$ yield after $10 \mathrm{~h}$ and $78 \%$ after $24 \mathrm{~h}$ (Table 1, entries 11 and 12). At this point, a conversion higher than $90 \%$ was achieved, with no significant improvement after a longer reaction time.

\begin{tabular}{lllll} 
Table 1: Optimization of the alkynylation of dipeptide 4a. \\
\hline 1
\end{tabular}

aReaction conditions: $0.20 \mathrm{mmol}$ 4a, $0.24 \mathrm{mmol}$ TIPS-EBX (1a), $0.010 \mathrm{mmol} \mathrm{AuCl}$ in $2 \mathrm{~mL}$ solvent were stirred at the indicated temperature and time. Isolated yields after column chromatography are given.

With the optimized conditions in hand, we investigated the scope of the reaction with different amino acids in the dipeptide (Scheme 2). With glycine as second amino acid, the desired product $5 \mathbf{b}$ could be obtained in $66 \%$ yield. The reaction was selective for tryptophan in the presence of other aromatic amino acids, such as phenylalanine or tyrosine (products $\mathbf{5 c}$ and $\mathbf{5 d}$ ). Serine and proline containing dipeptides $\mathbf{5 e}$ and $\mathbf{5 f}$ could also be obtained in $64 \%$ and $53 \%$ yield, respectively. The reaction was therefore general for dipeptides bearing tryptophan at the C-terminus. On the other hand, only traces of alkynylated dipeptide $\mathbf{5 g}$ with a tryptophan at the $\mathrm{N}$-terminus could be obtained under these reaction conditions. A first example of valine-tryptophan-valine tripeptide was also examined, and product $\mathbf{5 h}$ was isolated in $50 \%$ yield, demonstrating that alkynylation of tryptophan inside a peptide chain was possible. Unfortunately, only limited conversion was observed with N- or C-terminus unprotected peptides. Nevertheless, Hansen and co-workers recently demonstrated that $\mathrm{N}$ - and $\mathrm{C}$-termini unprotected peptides, as well as more complex peptides and even proteins, could be alkynylated using modified reaction conditions (10 $\mathrm{mol} \% \mathrm{AuCl}\left(\mathrm{SMe}_{2}\right)$, three equivalents TIPS-EBX (1a) and 2 mol \% trifluoroacetic acid as co-catalyst) [39]. They also demonstrated that the obtained silylalkyne products can be easily deprotected with fluoride sources to allow bioconjugation via cycloaddition with azides.

\section{Conclusion}

In conclusion, our work combined with the results of Hansen and co-workers has demonstrated that the gold-catalyzed alkynylation of indoles could be extended to tryptophan in peptides. When considering the scarcity of methods allowing the modification of tryptophan under mild conditions without requiring the installation of non-natural amino acids, the transformation will be highly useful for bioconjugation. A current limitation of the developed alkynylation reaction is the requirement for organic solvents. Investigations are currently ongoing in our laboratory for the development of water-compatible reagents and catalysts.

\section{Experimental}

\section{General procedure for the gold-catalyzed alkynylation}

The starting peptide 4 ( $0.20 \mathrm{mmol}, 1$ equiv) and TIPS-EBX (1a, $0.240 \mathrm{mmol}, 103 \mathrm{mg}, 1.2$ equiv) were added into a $5 \mathrm{~mL}$ test tube equipped with a stirring bar. Acetonitrile $(2 \mathrm{~mL})$ was added, then the reaction mixture was stirred at $40{ }^{\circ} \mathrm{C}$ for $2 \mathrm{~min}$. Gold(I) chloride ( $2.3 \mathrm{mg}, 10 \mu \mathrm{mol}, 0.05$ equiv) was added in one portion. The reaction tube was sealed and stirring was continued for $24 \mathrm{~h}$ at $40{ }^{\circ} \mathrm{C}$. Afterwards, the mixture was diluted with EtOAc $(50 \mathrm{~mL})$, and the organic layer was washed with a mixture of water $(2.5 \mathrm{~mL})$ and conc. $\mathrm{NaHCO}_{3}$ solution $(2.5 \mathrm{~mL})$, and then with brine $(20 \mathrm{~mL})$, and dried over $\mathrm{MgSO}_{4}$. The solvent was evaporated under reduced pressure and the resulting yellow oil was purified by column chromatography $\left(\mathrm{SiO}_{2}\right.$, hexane/EtOAc 3:1 to 2:3). The product was dried under reduced pressure, and washed into a vial with $\mathrm{Et}_{2} \mathrm{O}$. The solvent was evaporated under vacuum and dried under high vacuum (ca. $10^{-2}$ mbar) for several hours. 
<smiles>[X]C(=O)C(Cc1c[nH]c2ccccc12)NC(=O)C([R])NCCC</smiles>

4<smiles>[X]C(=O)C(Cc1c(C#C[SiH2]C(C)(F)F)[nH]c2ccccc12)NC(=O)C([R])NC(=O)[O-]</smiles>

5<smiles>COC(=O)C(Cc1c(C#C[Si](C)C)[nH]c2ccccc12)NC(=O)C(NC(C)(F)F)C(F)(F)F</smiles>

5a, $78 \%$<smiles>COC(=O)[C@H](Cc1c(C#C[SiH2]C(C)C)[nH]c2ccccc12)NC(=O)[C@H](Cc1ccc(O)cc1)NC(C)(C)C</smiles>

5d, $67 \%$<smiles>COC(=O)[C@H](Cc1c(C#C[SiH2]C(C)(F)F)[nH]c2ccccc12)NC(=O)CNC(=O)OCc1ccccc1</smiles>

5b, $66 \%$<smiles>COC(=O)[C@H](Cc1c(C#C[SiH2]C(F)(F)F)[nH]c2ccccc12)NC(=O)[C@@H](CO)NC(C)(C)C</smiles>

5e, $64 \%$<smiles>COC(=O)[C@H](Cc1c(C#C[SiH]C(=O)OCc2ccccc2)[nH]c2ccccc12)NC(=O)[C@H](Cc1ccccc1)NC(C)(C)C</smiles>

5c, $64 \%$

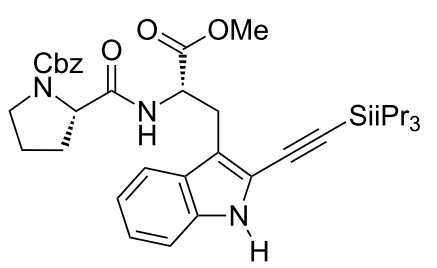

5f, $53 \%$<smiles>COC(=O)C(NC(=O)[C@H](Cc1c(C#C[SiH2]C(F)(F)F)[nH]c2ccccc12)C(F)(F)F)C(=O)NC(C)(F)F</smiles>

$\mathbf{5 g},<10 \%$<smiles>COC(=O)C(NC(=O)[C@H](Cc1c(C#C[SiH2]C(C)F)[nH]c2ccccc12)NC(=O)[C@@H](NC(=O)OCc1ccccc1)C(F)(F)F)C(F)(F)F</smiles>

$5 \mathrm{~h}, 50 \%$

\section{Supporting Information}

\section{Supporting Information File 1}

Experimental procedure and characterization data for all compounds. NMR spectra of new compounds. [http://www.beilstein-journals.org/bjoc/content/ supplementary/1860-5397-12-74-S1.pdf]

\section{Acknowledgements}

We thank the EPFL for funding and F. Hoffmann-La Roche Ltd. for an unrestricted research grant. The work of G.L.T. was supported by a Sciex-NMS ${ }^{\text {ch }}$ fellowship of the Swiss confederation.

\section{References}

1. Diederich, F.; Stang, P. J.; Tykwinski, R. R., Eds. Acetylene Chemistry: Chemistry, Biology and Material Science; Wiley-VCH: Weinheim, Germany, 2005.

2. Rostovtsev, V. V.; Green, L. G.; Fokin, V. V.; Sharpless, K. B. Angew. Chem., Int. Ed. 2002, 41, 2596. doi:10.1002/1521-3773(20020715)41:14<2596::AID-ANIE2596>3.0.CO $\cdot 2-4$

3. Lutz, J.-F. Angew. Chem., Int. Ed. 2007, 46, 1018 doi:10.1002/anie.200604050

4. Meldal, M.; Tornøe, C. W. Chem. Rev. 2008, 108, 2952. doi:10.1021/cr0783479

5. McKay, C. S.; Finn, M. G. Chem. Biol. 2014, 21, 1075 doi:10.1016/j.chembiol.2014.09.002

6. Stephanopoulos, N.; Francis, M. B. Nat. Chem. Biol. 2011, 7, 876. doi:10.1038/nchembio.720 
7. Takaoka, Y.; Ojida, A.; Hamachi, I. Angew. Chem., Int. Ed. 2013, 52, 4088. doi:10.1002/anie.201207089

8. Patterson, D. M.; Nazarova, L. A.; Prescher, J. A. ACS Chem. Biol. 2014, 9, 592. doi:10.1021/cb400828a

9. Yang, M.; Li, J.; Chen, P. R. Chem. Soc. Rev. 2014, 43, 6511. doi:10.1039/C4CS00117F

10. Boutureira, O.; Bernardes, G. J. L. Chem. Rev. 2015, 115, 2174. doi:10.1021/cr500399p

11. Koniev, O.; Wagner, A. Chem. Soc. Rev. 2015, 44, 5495. doi:10.1039/C5CS00048C

12. Chalker, J. M.; Bernardes, G. J. L.; Davis, B. G. Acc. Chem. Res. 2011, 44, 730. doi:10.1021/ar200056q

13. Kundu, R.; Ball, Z. T. Chem. Commun. 2013, 49, 4166. doi:10.1039/C2CC37323H

14. Toda, N.; Asano, S.; Barbas, C. F., III. Angew. Chem., Int. Ed. 2013, 52, 12592. doi:10.1002/anie.201306241

15. Abbas, A.; Xing, B.; Loh, T.-P. Angew. Chem., Int. Ed. 2014, 53, 7491. doi:10.1002/anie.201403121

16. Obermeyer, A. C.; Jarman, J. B.; Francis, M. B. J. Am. Chem. Soc. 2014, 136, 9572. doi:10.1021/ja500728c

17. Vinogradova, E. V.; Zhang, C.; Spokoyny, A. M.; Pentelute, B. L.; Buchwald, S. L. Nature 2015, 526, 687. doi:10.1038/nature15739

18. Joshi, N. S.; Whitaker, L. R.; Francis, M. B. J. Am. Chem. Soc. 2004, 126, 15942. doi:10.1021/ja0439017

19. Tilley, S. D.; Francis, M. B. J. Am. Chem. Soc. 2006, 128, 1080. doi:10.1021/ja057106k

20. Ban, H.; Gavrilyuk, J.; Barbas, C. F., III. J. Am. Chem. Soc. 2010, 132, 1523. doi:10.1021/ja909062q

21. Antos, J. M.; Francis, M. B. J. Am. Chem. Soc. 2004, 126, 10256. doi:10.1021/ja047272c

22. Antos, J. M.; McFarland, J. M.; lavarone, A. T.; Francis, M. B. J. Am. Chem. Soc. 2009, 131, 6301. doi:10.1021/ja900094h

23. Popp, B. V.; Ball, Z. T. J. Am. Chem. Soc. 2010, 132, 6660. doi:10.1021/ja101456c

24. Ruiz-Rodríguez, J.; Albericio, F.; Lavilla, R. Chem. - Eur. J. 2010, 16, 1124. doi:10.1002/chem.200902676

25. Preciado, S.; Mendive-Tapia, L.; Albericio, F.; Lavilla, R. J. Org. Chem. 2013, 78, 8129. doi:10.1021/j0400961x

26. Mendive-Tapia, L.; Preciado, S.; Garcia, J.; Ramon, R.; Kielland, N.; Albericio, F.; Lavilla, R. Nat. Commun. 2015, 6, No. 7160. doi:10.1038/ncomms 8160

27. Williams, T. J.; Reay, A. J.; Whitwood, A. C.; Fairlamb, I. J. S. Chem. Commun. 2014, 50, 3052. doi:10.1039/c3cc48481e

28. Reay, A. J.; Williams, T. J.; Fairlamb, I. J. S. Org. Biomol. Chem. 2015, 13, 8298. doi:10.1039/C5OB01174D

29. Zhu, Y.; Bauer, M.; Ackermann, L. Chem. - Eur. J. 2015, 21, 9980. doi:10.1002/chem.201501831

30. Perekalin, D. S.; Novikov, V. V.; Pavlov, A. A.; Ivanov, I. A.; Anisimova, N. Yu.; Kopylov, A. N.; Volkov, D. S.; Seregina, I. F.; Bolshov, M. A.; Kudinov, A. R. Chem. - Eur. J. 2015, 21, 4923. doi:10.1002/chem.201406510

31. Siti, W.; Khan, A. K.; de Hoog, H.-P. M.; Liedberg, B.; Nallani, M. Org. Biomol. Chem. 2015, 13, 3202. doi:10.1039/C4OB02025A

32. Kodama, K.; Fukuzawa, S.; Nakayama, H.; Sakamoto, K.; Kigawa, T.; Yabuki, T.; Matsuda, N.; Shirouzu, M.; Takio, K.; Yokoyama, S.; Tachibana, K. ChemBioChem 2007, 8, 232. doi:10.1002/cbic.200600432

33. Li, N.; Lim, R. K. V.; Edwardraja, S.; Lin, Q. J. Am. Chem. Soc. 2011, 133, 15316. doi:10.1021/ja2066913
34. Frei, R.; Waser, J. J. Am. Chem. Soc. 2013, 135, 9620. doi:10.1021/ja4044196

35. Frei, R.; Wodrich, M. D.; Hari, D. P.; Borin, P.-A.; Chauvier, C.; Waser, J. J. Am. Chem. Soc. 2014, 136, 16563. doi:10.1021/ja5083014

36. Abegg, D.; Frei, R.; Cerato, L.; Prasad Hari, D.; Wang, C.; Waser, J.; Adibekian, A. Angew. Chem., Int. Ed. 2015, 54, 10852. doi:10.1002/anie.201505641

37. Brand, J. P.; Charpentier, J.; Waser, J. Angew. Chem., Int. Ed. 2009, 48, 9346. doi:10.1002/anie.200905419

38. Tolnai, G. L.; Ganss, S.; Brand, J. P.; Waser, J. Org. Lett. 2013, 15, 112. doi:10.1021/ol3031389

39. Hansen, M. B.; Hubálek, F.; Skrydstrup, T.; Hoeg-Jensen, T. Chem. - Eur. J. 2016, 22, 1572. doi:10.1002/chem.201504462

\section{License and Terms}

This is an Open Access article under the terms of the Creative Commons Attribution License

(http://creativecommons.org/licenses/by/2.0), which permits unrestricted use, distribution, and reproduction in any medium, provided the original work is properly cited.

The license is subject to the Beilstein Journal of Organic Chemistry terms and conditions: (http://www.beilstein-journals.org/bjoc)

The definitive version of this article is the electronic one which can be found at: doi:10.3762/bjoc. 12.74 